Article

\title{
Conversion of Plant Secondary Metabolites upon Fermentation of Mercurialis perennis L. Extracts with two Lactobacteria Strains ${ }^{\dagger}$
}

\author{
Peter Lorenz ${ }^{1, *}$, Marek Bunse ${ }^{1}$, Simon Sauer ${ }^{1}$, Jürgen Conrad ${ }^{2}$, Florian C. Stintzing ${ }^{1}$ and \\ Dietmar R. Kammerer ${ }^{1}$ \\ 1 Department of Analytical Development \& Research, Section Phytochemical Research, \\ WALA Heilmittel GmbH, 73087 Bad Boll/Eckwälden, Germany; marek.bunse@wala.de (M.B.); \\ simon.sauer@wala.de (S.S.); florian.stintzing@wala.de (F.C.S.); dietmar.kammerer@wala.de (D.R.K.) \\ 2 Institute of Chemistry, Bioorganic Chemistry, Hohenheim University, Garbenstraße 30, 70599 Stuttgart, \\ Germany; juergen.conrad@uni-hohenheim.de \\ * Correspondence: peter.lorenz@wala.de; Tel.: +49-7164-930-7099 \\ + Dedicated to Prof. Dr. habil. Dr. h.c. Reinhold Carle on the occasion of his retirement.
}

Received: 13 April 2019; Accepted: 15 May 2019; Published: 17 May 2019

\begin{abstract}
Microbial fermentation of plant extracts with Lactobacteria is an option to obtain microbiologically stable preparations, which may be applied in complementary medicine. We investigated the metabolic conversion of constituents from Mercurialis perennis L. extracts, which were prepared for such applications. For this purpose, aqueous extracts were inoculated with two Lactobacteria strains, namely Pediococcus sp. (PP1) and Lactobacillus sp. (LP1). Both were isolated from a fermented M. perennis extract and identified by $16 \mathrm{~S}$ rRNA sequencing. After 1 day of fermentation, an almost complete conversion of the genuine piperidine-2,6-dione alkaloids hermidine quinone (3) and chrysohermidin (4) - both of them being oxidation products of hermidin (1) — was observed by GC-MS analysis, while novel metabolites such as methylhermidin (6) and methylhermidin quinone (7) were formed. Surprisingly, a novel compound plicatanin B (bis-(3-methoxy-1N-methylmaleimide); 8) was detected after 6 days, obviously being formed by ring contraction of 4 . An intermediate of a postulated reaction mechanism, isochrysohermidinic acid (14), could be detected by LC-MS. Furthermore, an increase in contents of the metabolite mequinol (4-methoxyphenol; 9) upon fermentation points to a precursor glycoside of $\mathbf{9}$, which could be subsequently detected by GC-MS after silylation and identified as methylarbutin (15). 15 is described here for M. perennis for the first time.
\end{abstract}

Keywords: dog's mercury; lactic acid fermentation; Pediococcus; Lactobacillus; benzilic acid rearrangement; decarboxylation; de-glycosylation

\section{Introduction}

Numerous biotechnological processes in the food, agriculture and herbal industries are based on lactic acid (LA) fermentation [1-4]. Besides growth inhibition of undesirable or pathogenic bacteria by LA, cell wall degrading enzymes of the lactic acid forming bacteria (LAB) contribute to the maceration of the plant matrix, therefore enhancing the bioavailability of the plant secondary metabolites. In addition, LAB may provide probiotic compounds [4,5]. Consequently, lactofermentation of medicinal plants is a worthwhile process to obtain extracts forgoing the use of organic solvents [6]. In such fermented extracts, genuine plant metabolites are either still intact, or are partially or completely converted into other constituents [7]. This bioconversion of plant constituents is similar to the metabolism found in the human intestine, with its microbiome being composed of a wide range of different LAB [8,9]. Fermentation of herbal extracts may further be used to enhance the functional features of medicinal 
plants or diminish toxic side effects [10-13]. We have recently studied the LAB fermentation chemistry of several medicinal plants [14-18]. However, numerous microbial conversion pathways of plant constituents still remain unknown, a reason to put further efforts into this research area.

Dog's Mercury (Mercurialis perennis L.) is an old medicinal plant mostly known from ethnomedicine [19]. Nowadays, the herbal parts are mainly used for the preparation of complementary medicinal products, which are externally applied e.g., for the treatment of poorly healing wounds, mammilitis of lactating women, hemorrhoids or conjunctivitis [19]. However, M. perennis is also regarded as poisonous when the plant is digested [20,21]. However, novel investigations into the toxicity of M. perennis are lacking in scientific literature and reports on fatal (lethal) effects of the herb are ambiguous and were probably due to confusion with annual dog's mercury (Mercurialis annua L.) [22]. The latter contains 3-cyanopyridine as a poisonous principle, which is not found in M. perennis [23]. We have extensively studied the phytochemistry of this plant genus for the last ten years. Meanwhile, numerous constituents of $M$. perennis and further Mercurialis species have been identified, e.g., the piperidine-dione alkaloid hermidin (1) [24-26], cinnamic acid depsides, flavonoids [27] and further low-molecular phenolics, terpenoids [26] and $n$-alkyl resorcinols [23,28,29]. Recently, we reported a first study on the metabolism of constituents upon spontaneous fermentation of M. perennis extracts, as a result of the action of the wild LAB flora [30]. Even though these investigations revealed the formation of novel metabolites, some of the enzymatic conversion pathways, especially of the N-containing compounds, are still poorly understood.

Consequently, the main focus of the current study was to investigate the conversion of M. perennis constituents under the influence of isolated Lactobacteria strains, aiming at the preparation of tailor-made extracts with predefined compound profiles, thus ensuring a constant quality of phytopharmaceutical preparations in the future. Particular attention was paid to the formation of novel metabolites and microbial (LAB) conversion pathways of M. perennis constituents, which were studied by GC-MS and LC-MS methods.

\section{Materials and Methods}

\subsection{Chemicals and Culture Media}

MRS agar (Lactobacillus-agar according to De Man, Rogosa and Sharpe) was purchased from Merck KGaA (Darmstadt, Germany). MRS broth was obtained from VWR International (Leuven, Belgium). Amberlite ${ }^{\circledR}$ IRA 402 anion exchanger (chloride form) was bought from Sigma-Aldrich Chemie $\mathrm{GmbH}$ (Steinheim, Germany), arbutin was from Carl Roth GmbH + Co. KG (Karlsruhe, Germany). $\mathrm{N}$-Methylmaleimide was obtained from ABCR GmbH (Karlsruhe, Germany) and dibenzo-18-crown-6 from Merck Schuchardt OHG (Hohenbrunn, Germany). Isochrysohermidin (mixture of $d, l$ - and meso-dimethyl-2,2',5,5' -tetrahydro-5,5'-dihydroxy-4,4'-dimethoxy-1,1'-dimethyl-2,2' -dioxo-1 $H, 1^{\prime} H-3,3^{\prime}$ -bipyrrole-5, $5^{\prime}$-dicarboxylate; $d, l-\mathbf{1 3}$ and meso-13, resp.) was synthesized according to a previously published procedure [31].

\subsection{Isolation, Gram-Staining and DNA Genotypization of the Lactobacteria}

Lactobacteria were isolated from the sediments of a fermentation batch, which was obtained from the vegetative parts of $M$. perennis and prepared according to a GHP protocol (German Homoeopathic Pharmacopoeia, procedure 34c) [32] after 3 months of incubation, by inoculation on MRS agar and incubation at $33^{\circ} \mathrm{C}$. Two different bacteria strains were segregated. Gram-staining of a smear of the bacteria strains was performed with an automated PREVI-Color Gram-staining system (bioMérieux Deutschland GmbH, Nürtingen, Germany) according to the manufacturer's specifications. For DNA genotyping, individual colonies of the pure strains were transferred into reaction tubes (Eppendorf, Germany) and stored at $-80^{\circ} \mathrm{C}$. The genomic DNA of both bacteria was isolated by bead beating, phenol- $\mathrm{CHCl}_{3}$ extraction, and iso- $\mathrm{PrOH}$ precipitation as described previously [33]. 16S rRNA genes of $1499 \mathrm{bp}$ long were amplified from genomic DNA using the universal primer GM3 
(5'-AGAGTTTGATCMTGGC-3') and GM4 (5'-TACCTTGTTACGACTT-3') in a polymerase chain reaction (PCR). The PCR was performed in $25 \mu \mathrm{L}$ batches composed as follows: $2.5 \mu \mathrm{L}$ dNTP (each $2.5 \mathrm{mM}), 0.25 \mu \mathrm{L} \mathrm{MgCl}_{2}(100 \mathrm{mM}), 1 \mu \mathrm{L}$ BSA $(30 \mathrm{mg} / \mathrm{mL}), 15.2 \mu \mathrm{L} \mathrm{H}_{2} \mathrm{O}, 0.25 \mu \mathrm{L}$ of each primer $(20$ pmol, 1U Go Taq ${ }^{\circledR}$ G2 DNA polymerase (Promega, USA) and $5 \mu \mathrm{L}$ Green Taq ${ }^{\circledR}$ reaction buffer. The PCR program consisted of an initial denaturation step at $95^{\circ} \mathrm{C}$ for $5 \mathrm{~min}, 31$ cycles at $95^{\circ} \mathrm{C}$ for $1 \mathrm{~min}, 42^{\circ} \mathrm{C}$ for $2 \mathrm{~min}$ and $72{ }^{\circ} \mathrm{C}$ for $1 \mathrm{~min}$, with a final extension at $72{ }^{\circ} \mathrm{C}$ for $10 \mathrm{~min}$. The PCR products were purified with a Peqlab Gold purification kit (VWR, Germany) according to the manual, and an aliquot was Sanger sequenced by GATC-Biotech (Eurofins Genomics GmbH, Ebersberg, Germany). Afterwards, sequences were aligned with the BioEdit program (Copyright ${ }^{\circledR}$ 2005, T. Hall, Ibis Therapeutics, Carlsbad, CA, USA) and compared with similar sequences of reference organisms using the BLAST function of the National Center for Biotechnology Information (NCBI) [34]. Finally, the analyzed DNA sequences were deposited at the NCBI GenBank [34]. For accession numbers see Table 1.

Table 1. Identification of the LAB strains, used in the present study, by $16 \mathrm{~S}$ rRNA gene sequencing.

\begin{tabular}{ccccc}
\hline $\begin{array}{c}\text { Isolate } \\
\text { (Strain) }\end{array}$ & $\begin{array}{c}\text { GenBank Accession } \\
\text { Number }^{1}\end{array}$ & $\begin{array}{c}\text { Sequence Length } \\
(\mathbf{b p})\end{array}$ & Closest Relative in NCBI $^{2}$ & Similarity $^{\text {L }}$ \\
\hline LP1 & MK841313.1 & 1083 & $\begin{array}{c}\text { Lactobacillus plantarum strain 2.7.17, } \\
\text { MK611349.1 }\end{array}$ & $100 \%$ \\
\hline PP1 & MK841045.1 & 1441 & $\begin{array}{c}\text { Pediococcus pentosaceus strain } \\
\text { CMGB-L16, MF348228.1 }\end{array}$ & $100 \%$ \\
\hline
\end{tabular}

${ }^{1}$ Type material, accessed on April 26, 2019. ${ }^{2}$ NCBI, National Center for Biotechnology Information [34].

\subsection{Plant Material, Extraction (General Procedure)}

Root parts of M. perennis were collected in September and aerial parts in March 2016, 2017 and 2018 in the mountain forest $565 \mathrm{~m}$ above sea level, close to Bad Boll/Eckwaelden (Germany), cleaned by rinsing with tap water and stored at $-80^{\circ} \mathrm{C}$ until investigation. Voucher specimens were deposited at the herbarium of the Institute of Botany, Hohenheim University (Germany), and the plant material was identified by Dr. R. Duque-Thüs (voucher number: HOH-020290). For extraction, roots and aerial parts of M. perennis $(65 \mathrm{~g})$ were immersed in water $(420 \mathrm{~mL})$ and bubbled with nitrogen $(15 \mathrm{~min})$. Subsequently, the plant material was minced for 3 min using an Ultra-turrax ${ }^{\circledR}(15,000 \mathrm{rpm}$; IKA-Werke $\mathrm{GmbH}$ and Co. KG, Staufen, Germany), again treated with $\mathrm{N}_{2}$ and the slurry was allowed to stand for $24 \mathrm{~h}$ at $+4{ }^{\circ} \mathrm{C}$. Then, the plant material (sediment) was removed by vacuum suction over Celite.

\subsection{Fermentation of Aqueous M. perennis Extracts with Isolated Lactobacteria Strains}

Fermentations were performed in $50 \mathrm{~mL}$ or $500 \mathrm{~mL}$ batches. For this purpose, the filtrate was sterilized by filtration of the aqueous $M$. perennis extract over a sterile $0.2 \mu \mathrm{m}$ cellulose acetate membrane (VWR International, Bruchsal, Germany). Afterwards, the filtrates were inoculated with overnight cultures of PP1 and LP1 in MRS broth (1 mL each) with a bacteria concentration of $2.6 \times 10^{8}$ cells $/ \mathrm{mL}$ and $5.1 \times 10^{8}$ cells $/ \mathrm{mL}$, respectively, and incubated at $33^{\circ} \mathrm{C}$. For semi-quantitative investigations (stage monitoring) fermentation was performed in triplicate $(n=3)$. Culture broths were slightly agitated once a day to shake up precipitates. At $t=0,1,3,6$ and 14 days, samples of the fermentation broth (20 mL each) were withdrawn for GC-MS analysis and extracted with AcOEt $(2 \times 20 \mathrm{~mL})$. After drying $\left(\mathrm{Na}_{2} \mathrm{SO}_{4}\right)$, the AcOEt extracts were filtered over a folded filter and the solvent was removed by vacuum rotary evaporation. The obtained residues were re-dissolved in $0.2 \mathrm{~mL}$ AcOEt and used for GC-MS analyses. For semi-quantitative determinations, the AcOEt extract was spiked with $1 \mathrm{~mL}$ of an $n$-eicosane AcOEt solution $(0.025 \mathrm{mg} / \mathrm{mL})$ prior to rotary evaporation. The increase of peak areas (Atx) was analyzed by GC-MS and calculated according to Equation (1):

$$
\left(\frac{\left(\frac{A t x}{A S t x}-\frac{A t 0}{A S t 0}\right)}{A S t 0}\right) \times 100=\text { increase in peak area } \%
$$


where Atx is the area of the analyte at a certain time, At0 is the area of the analyte at $\mathrm{t}=0$ days, ASt $x$ is the area of the internal standard at a certain time and Ast 0 is the area of the internal standard at $\mathrm{t}=$ 0 days.

\subsection{GC-MS Analyses}

GC-MS analyses were performed with a PerkinElmer Clarus 500 gas chromatograph with split injection (split ratio 30:1, injection volume $1.0 \mu \mathrm{L}$ ) in conjunction with a single quadrupole mass spectrometer. The column and temperature program were used in accordance with a previous publication [31].

\subsection{NMR Spectroscopy}

NMR spectra were recorded in $\mathrm{CDCl}_{3}$ or $\mathrm{CD}_{3} \mathrm{OD}$ at 500 or $600\left({ }^{1} \mathrm{H}\right)$ and 125 or $150 \mathrm{MHz}\left({ }^{13} \mathrm{C}\right)$ using a $500 \mathrm{MHz}$ Varian Inova and a $600 \mathrm{MHz}$ Bruker Avance III HD NMR spectrometer mounted with a BBO Prodigy cryo-probe. Chemical shifts are reported in $\delta[\mathrm{ppm}]$ and refer to residual (non-deuterated) solvent signals of $\mathrm{CDCl}_{3}\left({ }^{1} \mathrm{H}: 7.27 ;{ }^{13} \mathrm{C}: 77.00 \mathrm{ppm}\right)$ and $\mathrm{CD}_{3} \mathrm{OD}\left({ }^{1} \mathrm{H}: 3.31 ;{ }^{13} \mathrm{C}: 49.20 \mathrm{ppm}\right)$. For NMR spectra evaluation the program SpinWorks 3.1.7. (Copyright ${ }^{\circledR}$ 2010, K. Marat, University of Manitoba, USA) was applied.

\subsection{Enrichment of Isochrysohermidinic Acid (14) from an Aqueous M. perennis Extract}

Frozen roots of $M$. perennis $(65.5 \mathrm{~g})$ were extracted with water $(420 \mathrm{~mL})$ under nitrogen $\left(\mathrm{N}_{2}\right)$ atmosphere for $12 \mathrm{~h}$ as described above. After filtration, the obtained aqueous extract was kept for another $12 \mathrm{~h}$ in a refrigerator. For the isolation of isochrysohermidinic acid (14) the extract (385 mL) was applied onto an Amberlite ${ }^{\circledR}$ IRA 402 anion exchanger column $(1=25 \mathrm{~cm}, \mathrm{~d}=3 \mathrm{~cm})$, which was conditioned with $0.1 \mathrm{~N} \mathrm{HCl}(1 \mathrm{~L})$ and water $(4 \mathrm{~L})$. After extract application, the column was washed with water (2 L, fraction discarded) and the target material eluted with $0.1 \mathrm{~N} \mathrm{HCl}(600 \mathrm{~mL})$. Finally, the aqueous $\mathrm{HCl}$ was distilled off using a vacuum rotary evaporator to yield a brown hemi-crystalline syrup $(0.61 \mathrm{~g})$, which was kept at $-30{ }^{\circ} \mathrm{C}$ until investigation.

\subsection{RP-HPLC-(DAD)/ESI-MS Analyses}

Liquid chromatographic / mass spectrometric analyses (LC-MS) were performed using an Agilent 1200 HPLC system (Agilent Technologies Inc., Palo Alto, USA) coupled to an HCTultra ion trap (Bruker Daltonik GmbH, Bremen, Germany) and an ESI source, controlled by Agilent Chemstation for LC 3D systems (Rev. B01.03SR1 (204)) and EsquireControl software (V7.1) [31]. A Kinetex ${ }^{\circledR} \mathrm{C}_{18}$ reversed-phase column (2.6 $\mu \mathrm{m}$ particle size, $150 \times 2.1 \mathrm{~mm}$ i.d., Phenomenex Ltd., Aschaffenburg, Germany) was used for chromatographic separation at $25^{\circ} \mathrm{C}$ and a flow rate of $0.21 \mathrm{~mL} / \mathrm{min}$. The mobile phase consisted of $\mathrm{HCOOH} / \mathrm{H}_{2} \mathrm{O}$ 0.1:99.9 (v/v; eluent A) and MeCN (mobile phase B). The injection volume of each sample was $10 \mu \mathrm{L}$, and the gradient used was as follows: $0-10 \mathrm{~min}, 0 \%-10 \% \mathrm{~B} ; 10-25 \mathrm{~min}, 10 \% \mathrm{~B}$; 25-60 min, 10\%-23\% B; 60-62 min, 23\% B; 62-65 min, 23\%-100\% B; 65-70 min, $100 \%$ B; 70-75 min, $100 \%-0 \% \mathrm{~B} ; 75-85 \mathrm{~min}, 0 \% \mathrm{~B}$. The MS system was operated in the positive ionization mode applying the following parameters: capillary voltage: $-4000 \mathrm{~V}$, dry gas $\left(\mathrm{N}_{2}\right)$ flow: $9.00 \mathrm{~L} / \mathrm{min}$ with a capillary temperature of $365{ }^{\circ} \mathrm{C}$; nebulizer pressure: 35 psi. Full scan mass spectra $(\mathrm{m} / \mathrm{z} 50-1000)$ of HPLC eluates were recorded in the auto MS/MS mode during chromatographic separation. To obtain further structural information, collision induced dissociation (CID) experiments were performed by MS/MS fragmentation of $[\mathrm{M}+\mathrm{H}]^{+}$ions.

\subsection{Isolation of Plicatanin B (8) and N-Methylmaleimide (5) from a Fermentation Broth of M. perennis}

A fermentation broth of $M$. perennis $(1.37 \mathrm{~L})$, prepared from aerial parts according to a GHP procedure [32] was extracted with AcOEt $(4 \times 300 \mathrm{~mL})$, the AcOEt extract was dried $\left(\mathrm{Na}_{2} \mathrm{SO}_{4}\right)$, filtered by vacuum suction and the solvent was removed by vacuum rotary evaporation to yield an olive 
coloured syrup (1.25 g). The latter was applied to vacuum liquid chromatography (VLC), using a silica column (100 $\mathrm{g} \mathrm{SiO}_{2}$ ) and a $\mathrm{CH}_{2} \mathrm{Cl}_{2} / \mathrm{MeOH}$ gradient (from 100:0 to 95:5, $v / v$ ). Two fractions containing the target compounds were separated (identified by TLC), unified and dried by rotary evaporation yielding a residue of $0.17 \mathrm{~g}$. Compounds 5 and 8 were isolated from the latter by centrifugally accelerated thin layer chromatography (CTLC, Chromatotron ${ }^{\circledR}$, T-Squared Technology, San Bruno, CA, USA) [35] with a $2 \mathrm{~mm}$ layer $\left(\mathrm{SiO}_{2} /\right.$ gypsum/fluorescence indicator $\left.254 \mathrm{~nm}, 45: 18: 1.2(w / w / w)\right)$, applying an $n$-hexane/AcOEt gradient from 100:0 to 80:20 (v/v). The pure compounds $5(31.3 \mathrm{mg})$ and 8 (7.5 mg) were obtained from the corresponding fractions after solvent removal.

\subsection{Synthesis of Reference Compounds}

\subsubsection{Synthesis of Plicatanin B (bis-(3-methoxy-1- $N$-methyl-maleimide); 8)}

A solution of rac-isochrysohermidin $(\mathbf{1 3}, 0.177 \mathrm{~g}, 0.444 \mathrm{mmol})$ in THF/MeOH $(1: 1, v / v, 40 \mathrm{~mL})$ was treated under $\mathrm{N}_{2}$ atmosphere with a $0.25 \mathrm{M}$ aqueous $\mathrm{NaOH}$ solution $(8 \mathrm{~mL})$. After stirring at room temperature $(22 \mathrm{~h})$ the solvent was removed by vacuum rotoevaporation $\left(\mathrm{T}=38^{\circ} \mathrm{C}, p<22 \mathrm{mbar}\right)$. The remaining residue was dissolved in water $(120 \mathrm{~mL})$ and the $\mathrm{pH}$ adjusted to 7.0 by addition of $\mathrm{AcOH}$. Subsequently, $20 \mathrm{~mL}$ of a freshly prepared aqueous $0.62 \%$ bromine solution $\left(1 \mathrm{~mL}, 3.12 \mathrm{~g} \mathrm{Br}_{2}\right.$ dissolved by sonication in $0.5 \mathrm{~L}$ water) was added and the reaction mixture stirred for $7 \mathrm{~h}$ at room temperature, while the color turned from orange into yellow-green. Subsequently, the aqueous solution was saturated with $\mathrm{NaCl}$ and extracted with AcOEt $(3 \times 100 \mathrm{~mL})$. The combined extracts were dried $\left(\mathrm{Na}_{2} \mathrm{SO}_{4}\right)$ and the solvent distilled off to yield the crude product $(0.085 \mathrm{~g})$. The latter was purified by CTLC (Chromatotron ${ }^{\circledR}$, conditions see above). The elution of the target product was performed with a hexane/AcOEt gradient from 100:0 to 60:40 (v/v). Yield: $0.0508 \mathrm{~g}\left(40.8 \%\right.$ of the theory). $\mathrm{R}_{\mathrm{f}}\left(\mathrm{SiO}_{2}\right.$; $\mathrm{CH}_{2} \mathrm{Cl}_{2} / \mathrm{MeOH}$ 19.5:0.5 (v/v)) 0.51. GC/MS purity: 98.5\% (at retention time $36.1 \mathrm{~min}$ ), GC/MS data see Table 2. UV/VIS (MeCN): 235 (4.36), 350 (3.18). ${ }^{1} \mathrm{H}-\mathrm{NMR}\left(\mathrm{CDCl}_{3}, 600 \mathrm{MHz}\right): 4.14$ (s, H-(C7, $\left.\left.7^{\prime}\right)\right), 3.06$ (s, H-(C6, 6 $\left.\left.6^{\prime}\right)\right) .{ }^{13} \mathrm{C}-\mathrm{NMR}\left(\mathrm{CDCl}_{3}, 150 \mathrm{MHz}\right): 169.57\left(\mathrm{C}\left(2,2^{\prime}\right)\right), 164.93\left(\mathrm{C}\left(5,5^{\prime}\right)\right), 156.70\left(\mathrm{C}\left(3,3^{\prime}\right)\right), 99.69$ $\left(C\left(4,4^{\prime}\right)\right), 59.71\left(C\left(7,7^{\prime}\right)\right), 24.10\left(C\left(6,6^{\prime}\right)\right)$. The NMR shifts (see also Supplementary Material, Figures S5 and S6) are in agreement with literature data [36].

\subsubsection{Synthesis of 3-Bromo-1N-methylmaleimide}

The compound was synthesized according to a modified literature procedure [37]. In brief, a solution of $N$-methylmaleimide $(2.50 \mathrm{~g}, 22.50 \mathrm{mmol})$ in $\mathrm{MeOH}(110 \mathrm{~mL})$ was treated dropwise with bromine $\left(\mathrm{Br}_{2}, 2.6 \mathrm{~mL}, 8.11 \mathrm{~g}, 50.75 \mathrm{mmol}\right)$ and stirred for $24 \mathrm{~h}$ at room temperature Then, the solvent was removed by vacuum rotoevaporation. To remove $\mathrm{Br}_{2}, \mathrm{MeOH}(2 \times 50 \mathrm{~mL})$ was added and distilled off in vacuo. The obtained orange residue was dissolved in THF $(100 \mathrm{~mL}), \mathrm{Et}_{3} \mathrm{~N}(5.4 \mathrm{~mL}, 3.94 \mathrm{~g}$, $38.94 \mathrm{mmol}$ ) was added dropwise under stirring and the reaction mixture was stirred for further $10 \mathrm{~h}$ at room temperature Afterwards, the precipitated ammonium salts were filtered off by vacuum suction, washed with THF $(2 \times 50 \mathrm{~mL})$, and the solvent was removed from the filtrate by rotoevaporation. The crude product $(5.1 \mathrm{~g}$ ) was purified by vacuum liquid chromatography (VLC) on silica using an $n$-hexane/AcOEt gradient (from 100:0 to 70:30, $v / v$ ). The corresponding fractions containing the target product (identified by TLC) were combined, the solvent was distilled off and the obtained yellow solid residue was washed with $n$-hexane $(2 \times 50 \mathrm{~mL})$. The pure compound was obtained after recrystallization from $n$-hexane. Yield: $2.90 \mathrm{~g}\left(67.8 \%\right.$ of the theory). Mp. $90.5^{\circ} \mathrm{C}, \mathrm{Mp}$.Lit. $77-79{ }^{\circ} \mathrm{C}$ [37]. $\mathrm{R}_{\mathrm{f}}\left(\mathrm{SiO}_{2} ; \mathrm{CH}_{2} \mathrm{Cl}_{2} / \mathrm{MeOH}\right.$ 19.5:0.5 (v/v)) 0.68. UV/VIS (MeCN): 238 (4.17). GC/MS purity (70 eV): $>99.9$ \% (retention time $9.9 \mathrm{~min}): \mathrm{m} / \mathrm{z} 191,189(59 / 61)\left[\mathrm{M}^{+}\left({ }^{81} \mathrm{Br} /{ }^{79} \mathrm{Br}\right)\right], 163,162(3 / 4), 134,132(42 / 44), 110(8)$, 106, 104 (35/36), 82 (18), 66 (8), 56 (14), 53 (100). 
Table 2. Gas chromatography-mass spectrometry (GC-MS) data of compounds identified in unfermented and fermented root extracts of M. perennis.

\begin{tabular}{|c|c|c|}
\hline Compound & Retention Time (min) & Characteristic Mass Signals, $m / z$ (\% BPI) \\
\hline mequinol (4-methoxyphenol; 9) & 11.1 & $124\left(\mathrm{M}^{+}, 100\right), 109(98), 95(2), 81(46), 65(5), 53(15)^{1}$ \\
\hline 3-methoxy-1N-methyl-maleimide (5) & 11.9 & $141\left(\mathrm{M}^{+}, 23\right), 123(8), 113(12), 112(25), 84(23), 69(100), 56(9), 53(7)$ \\
\hline (-)-cis-myrtanol (10) & 12.8 & $\begin{array}{l}136\left(\left[\mathrm{M}-\mathrm{H}_{2} \mathrm{O}\right]^{+}, 11\right), 123(68), 121 \text { (42), } 107 \text { (15), } 95 \text { (28), } 93 \text { (100), } 81 \text { (65), } 79 \text { (38), } 69 \text { (73), } \\
67(80), 55(45) \text { 1, }\end{array}$ \\
\hline 3-methylhermidin (6) & 16.6 & $\begin{array}{l}185\left(\mathrm{M}^{+}, 100\right), 170(65), 156(68), 142(30), 128(20), 126(15), 114(13), 99(17), 83(40), \\
68(74), 58(64)\end{array}$ \\
\hline 3,4-dimethoxyphenol (11) & 17.0 & $154\left(\mathrm{M}^{+}, 100\right), 139(96), 125(4), 111(48), 96(11), 93(27), 81(9), 69(16), 65(18), 55(18)^{1}$ \\
\hline 3-methylhermidin quinone (7) & 18.7 & $183\left(\mathrm{M}^{+}, 52\right), 154(1), 137(2), 126(6), 112(3), 98(23), 83(100), 70(8), 55(8)$ \\
\hline hermidin quinone (3) & 20.9 & $169\left(\mathrm{M}^{+}, 35\right), 142(0.4), 112(35), 84(21), 69(100), 56(7), 53(9)^{1}$ \\
\hline plicatanin B (bis-(3-methoxy-1N-methyl-maleimide); 8) & 35.8 & $\begin{array}{l}280\left(\mathrm{M}^{+}, 100\right), 265(20), 251(24), 237(11), 208(17), 195(6), 180(35), 178(22), 166(21), \\
152(20), 123(45), 109(5), 95(72), 80(37), 72(16), 67(8), 53(6)\end{array}$ \\
\hline 3-(3-methoxy-1N-methyl-malimido)-hermidin quinone (12) & 40.0 & $\begin{array}{l}308\left(\mathrm{M}^{+}, 67\right), 280(54), 265(14), 251(27), 237(13), 223(11), 208(72), 195(34), 180(76), \\
166(13), 152(30), 123(62), 109(8), 95(100), 80(57), 69(10), 53(11)\end{array}$ \\
\hline chrysohermidin (bis-(hermidin quinone); 4) & 43.9 & $\begin{array}{l}336\left(\mathrm{M}^{+}, 9\right), 321(74), 308(12), 280(53), 265(23), 251(23), 236(76), 208(62), 195(25), \\
180(100), 167(11), 152(37), 123(52), 111(13), 95(94), 80(58), 68(13), 53(11)^{1}\end{array}$ \\
\hline
\end{tabular}




\subsubsection{Synthesis of 3-Methoxy-1N-methylmaleimide (5)}

3-Bromo-1 $\mathrm{N}$-methylmaleimide (1.00 g, $5.263 \mathrm{mmol})$ and dibenzo-18-crown-6 (0.197 g, $0.547 \mathrm{mmol})$ were dissolved in MeCN $(30 \mathrm{~mL})$, stirred for $10 \mathrm{~min}$ and $\mathrm{KOMe}(0.40 \mathrm{~g}, 5.704 \mathrm{mmol})$ was added. After stirring in an oil bath $\left(40{ }^{\circ} \mathrm{C}, 3 \mathrm{~h}\right)$, the reaction was quenched by addition of saturated aqueous $\mathrm{NH}_{4} \mathrm{Cl}$ solution (prepared from $30 \mathrm{~g} \mathrm{NH}_{4} \mathrm{Cl}$ and $90 \mathrm{~mL}$ water). Thereafter, the mixture was extracted with $\mathrm{CHCl}_{3}(4 \times 50 \mathrm{~mL})$, the combined $\mathrm{CHCl}_{3}$ extracts were dried $\left(\mathrm{Na}_{2} \mathrm{SO}_{4}\right)$ and the solvent removed by vacuum rotoevaporation to yield a crude residue $(1.15 \mathrm{~g})$. The pure compound 5 was obtained from the latter by repeated VLC on silica $60 \mathrm{G}\left(2 \times 60 \mathrm{~g} \mathrm{SiO}_{2}\right)$, utilizing an $n$-hexane/AcOEt gradient from 100:0 to $60: 40(v / v)$. The fractions containing 5 (detected by TLC) were unified, the solvent was removed by rotoevaporation, and the product was dried in vacuo. Yield: $0.128 \mathrm{~g}$ (17.2\% of the theory), white solid. $\mathrm{R}_{\mathrm{f}}\left(\mathrm{SiO}_{2} ; \mathrm{CH}_{2} \mathrm{Cl}_{2} / \mathrm{MeOH} 19.5: 0.5(v / v)\right)$ 0.57. GC/MS purity $(70 \mathrm{eV}): 91 \%$ (retention time $11.9 \mathrm{~min})$ : For MS data see Table 2. ${ }^{1} \mathrm{H}-\mathrm{NMR}\left(\mathrm{CDCl}_{3}, 500 \mathrm{MHz}\right): 5.41$ (s, H-(C4)), 3.93 (s, H-(C7)), 2.99 (s, H-(C6)). ${ }^{13} \mathrm{C}-\mathrm{NMR}\left(\mathrm{CDCl}_{3}, 125 \mathrm{MHz}\right): 170.19$ (C(2)), 165.65 (C(5)), 161.07 (C(3)), 96.19 (C(4)), $58.85(\mathrm{C}(7)), 23.44(\mathrm{C}(6))$. The NMR shifts (see also Supplementary Material, Figures S3 and S4) are in agreement with literature data [38].

\subsubsection{Synthesis of Methylarbutin (4-Methoxyphenol- $\beta$-D-glucopyranoside; 15)}

Arbutin (4-hydroxyphenol- $\beta$-D-glucoside, $16.74 \mathrm{~g}, 61.50 \mathrm{mmol}$ ) was dissolved in aqueous $1 \%$ $\mathrm{KOH}$ solution $(w / v, 430 \mathrm{~mL}, 76.64 \mathrm{mmol})$ under $\mathrm{N}_{2}$ atmosphere. Then, dimethylsulfate $(5.85 \mathrm{~mL}, 7.78 \mathrm{~g}$, $61.68 \mathrm{mmol}$ ) was added dropwise and the mixture was stirred $1 \mathrm{~h}$ at room temperature and further $1 \mathrm{~h}$ at $110^{\circ} \mathrm{C}$ in an oil bath. After cooling to room temperature the reaction mixture was extracted with AcOEt $(3 \times 430 \mathrm{~mL})$ and the combined AcOEt extracts were dried $\left(\mathrm{Na}_{2} \mathrm{SO}_{4}\right)$. After filtration, the solvent was removed in vacuo to yield the crude product $(2.42 \mathrm{~g}, 13.7 \%$ of the theory). The latter was recrystallized from AcOEt. White solid. M.p. $172{ }^{\circ} \mathrm{C}$ (M.p.Lit $=170{ }^{\circ} \mathrm{C}$ [39]). $\mathrm{R}_{\mathrm{f}}\left(\mathrm{SiO}_{2} ; \mathrm{MeOH} / \mathrm{AcOEt} / \mathrm{H}_{2} \mathrm{O} 3: 15: 2\right.$ $(v / v / v))$ 0.47. UV/VIS (MeCN): 225 (4.07), 285 (3.42). GC-MS purity (as TMS derivative, $70 \mathrm{eV}$ ): $>90 \%$ (retention time $43.5 \mathrm{~min}$ ), impurity: arbutin; $\mathrm{m} / z 469$ (1), 450 (7), 361 (43), 331 (4), 319 (5), 271 (13), 243 (12), 217 (33), 196 (92), 191 (8), 169 (18), 147 (34), 129 (19), 117 (7), 103 (16), 73 (100). ${ }^{1} \mathrm{H}-\mathrm{NMR}\left(\mathrm{CD}_{3} \mathrm{OD}\right.$, $600 \mathrm{MHz}): 7.05\left(d, J_{\mathrm{H} 2,6 / \mathrm{H} 3,5} 9.1, \mathrm{H}-(\mathrm{C} 2,6)\right), 6.83\left(d, J_{\mathrm{H} 3,5 / \mathrm{H} 2,6} 9.1, \mathrm{H}-(\mathrm{C} 3,5)\right), 4.77\left(d, J_{\mathrm{H} 3,5 / \mathrm{H} 2,6} 7.5\right.$, $\left.\mathrm{H}-\left(\mathrm{C}^{\prime}\right)\right), 3.88\left(d d, J_{\mathrm{Ha}-6^{\prime} / \mathrm{Hb}-6^{\prime}} 12.0, J_{\mathrm{Ha}-6^{\prime} / \mathrm{H}-5^{\prime}} 1.8, \mathrm{Ha}-\left(\mathrm{C} 6^{\prime}\right)\right), 3.75\left(s, \mathrm{H}-(\mathrm{C} 7), \mathrm{OCH}_{3}\right), 3.70\left(d d, J_{\mathrm{Hb}-6^{\prime} / \mathrm{Ha}-6^{\prime}}\right.$ \left. 12.0, J J ${\mathrm{Hb}-6^{\prime} / \mathrm{H}-5^{\prime}}^{5} .3, \mathrm{Hb}-\left(\mathrm{C} 6^{\prime}\right)\right), 3.45-3.36\left(m, \mathrm{H}-\left(\mathrm{C}^{\prime}, 3^{\prime}, 4^{\prime}, 5^{\prime}\right)\right) .{ }^{13} \mathrm{C}-\mathrm{NMR}\left(\mathrm{CD}_{3} \mathrm{OD}, 150 \mathrm{MHz}\right): 156.84$ $(C(4)), 153.43(C(1)), 119.41(C(2,6)), 115.64(C(3,5)), 103,67\left(C\left(1^{\prime}\right)\right), 78.29\left(C\left(3^{\prime}\right)\right), 78.21\left(C\left(5^{\prime}\right)\right), 75.18$ $\left(\mathrm{C}\left(2^{\prime}\right)\right), 71,63\left(\mathrm{C}\left(4^{\prime}\right)\right), 62.76\left(\mathrm{C}\left(6^{\prime}\right)\right), 56.24(\mathrm{C}(7))$. The NMR data (see also Supplementary Materials, Figures S7 and S8) are in agreement with literature data [39,40].

\section{Results and Discussion}

\subsection{Identification of the Lactobacteria in Fermented Aqueous M. perennis Extracts}

Since the LAB microflora of fermented M. perennis extracts has not been studied so far, we isolated two bacterial strains as pure cultures from sediments of a fermentation broth after 3 months of incubation. By microscopic examination, it was demonstrated that both bacterial strains were Gram-(+), while one strain consisted of cocci and the other of rod-shaped bacteria (bacilli).

The isolated strains LP1 (MK841313) and PP1 (MK841045) were identified by 16S rRNA gene sequence analysis (Table 1) as members of the genus Lactobacillus and Pediococcus, respectively [41,42]. The closest relatives show a $100 \%$ similarity with Lactobacillus plantarum and Pediococcus pentosaceus (Table 1). Both bacteria are typical homo-fermentative representatives of the LAB flora $[1,43]$ and often occur in fermented plant materials [41,44].

\subsection{Fermentation of M. perennis with the Lactobacteria Isolates and GC-MS Analysis of the Metabolites}

To study the bioconversion of plant metabolites in a fermentation model, roots of $M$. perennis were used in a first step because of high hermidin (1) content compared to herbal parts containing lower 
amounts of this alkaloid [26]. Hermidin (1) is an oxygen-sensitive compound which is only stable under reducing physiological conditions. In the presence of oxygen, $\mathbf{1}$ is easily oxidized forming the blue anionic radical cyanohermidin (2) (Figure 1). This occurs when plant cell integrity is damaged, e.g., after harvest or upon plant extraction [24,25]. Consequently, 2 further reacts forming the oxidation products hermidin quinone (3) and chrysohermidin (4), which display multifaceted downstream reactions in aqueous solvents [31]. In the present study $M$. perennis roots, and in a second step also herbal parts, were macerated with water under nitrogen $\left(\mathrm{N}_{2}\right)$ atmosphere to prevent oxidation reactions of the plant constituents.

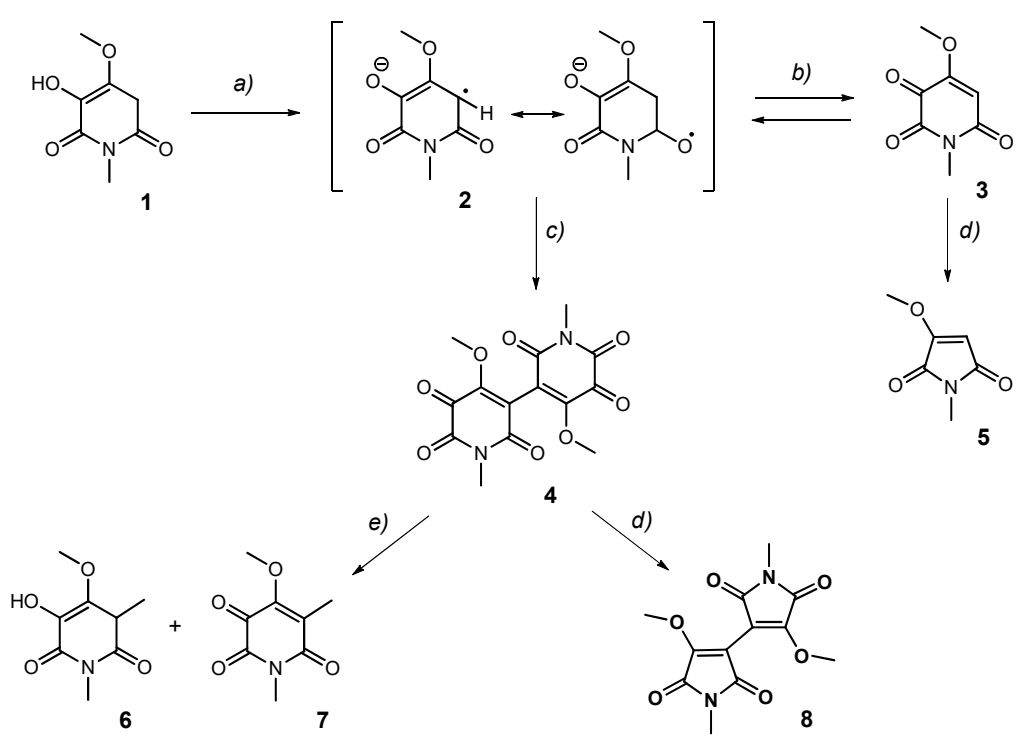

Figure 1. Proposed metabolic pathway of hermidin (1). Conversion by oxidation $(a-c)$ and catabolization $(e-d)$ upon the action of LAB. (a) Deprotonation and oxidation $\left(-2 \mathrm{H}^{+} ;-\mathrm{e}^{-}\right)$. (b) Oxidation $\left(-\mathrm{e}^{-}\right)$. (c) Dimerization and protonation $\left(+2 \mathrm{H}^{+}\right)$. (d) Benzilic acid rearrangement and oxidative decarboxylation $\left(-\mathrm{CO}_{2},-2 \mathrm{H}^{+}\right)$. (e) Partial six-ring degradation.

After sterile filtration, the obtained aqueous extracts ( $\mathrm{pH}$ 7.2) were incubated either with the LAB strain PP1 or LP1. The pH of the fermentation broths readily declined to 3.8-3.5 after 1 to 2 days of incubation, indicating the formation of LA, while from this point on the $\mathrm{pH}$ remained constant over the entire fermentation period. After time intervals of $t=0,1,3,6$ and 14 days samples were withdrawn, extracted with AcOEt and investigated by GC-MS (EI mode). In the AcOEt extracts of an unfermented aqueous sample ( $t=0$ days, Figure 2A) several known compounds, like mequinol (4-methoxyphenol; 9, $m / z$ 124), (-)-cis-myrtanol (10, $m / z$ 154), 3,4-dimethoxyphenol (11, $m / z ~ 154)$, hermidin quinone $(\mathbf{3}, m / z$ 169) and chrysohermidin (4, $m / z$ 336), were detected by GC-MS at retention time 11.1, 12.8, 17.0, 20.9, and 43.9 min, respectively, and assigned based on their mass spectra and comparison with previously published data (Figure 1, Figure 2A and Table 2) [26]. Already after 1 day of fermentation the monomeric hermidin quinone (3) and the dimeric chrysohermidin (4) were almost completely degraded, while two novel metabolites at retention time 16.6 and $18.7 \mathrm{~min}$ were analyzed by GC-MS (Figure 2B, exemplarily shown for a PP1 culture broth, while inoculation with LP1 revealed a similar pattern).

The odd-numbered molecular ion peaks at $m / z 185$ and 183 and distinct fragmentation patterns $[\mathrm{M}-\mathrm{MeN}]^{+}$and $[\mathrm{M}-\mathrm{MeN}-\mathrm{CO}]^{+}$(Table 2 ) indicate these compounds to be methoxy-N-methylpiperidione derivatives, amplified by one $\mathrm{C} 1$ unit. Based on mass spectral similarities to literature data of ethylhermidin and ethylhermidin quinone (Mw 199 and 197 Da, respectively), formerly detected in M. perennis extracts fermented with a mixed LAB flora [30], we conclude that the novel constituents are methylhermidin (6) and methylhermidin quinone (7) (Figure 1). Starting from hermidin (1), the spontaneously formed oxidation products 3 and 4 (Figure 1) are supposedly converted by enzymes like decarboxylases. One pathway leads to the degradation of one six-membered ring of chrysohermidin 
(4) to form the methylhermidin derivatives 6 and 7. The formation of these latter compounds 6 and 7 by isolated LAB strains, as observed in this study, is different from previously published results, where $M$. perennis extracts were fermented by a spontaneously developed LAB flora. In contrast, spontaneous fermentation due to the wild microbial flora converts 4 into ethylhermidins [30]. One reason might be the different activities of the enzymes of a mixed LAB microflora compared to isolated strains. Interestingly, the previously reported metabolites ethylhermidin and ethylhermidin quinone were found in the current study only in trace amounts in fermentation batches with PP1 and LP1.

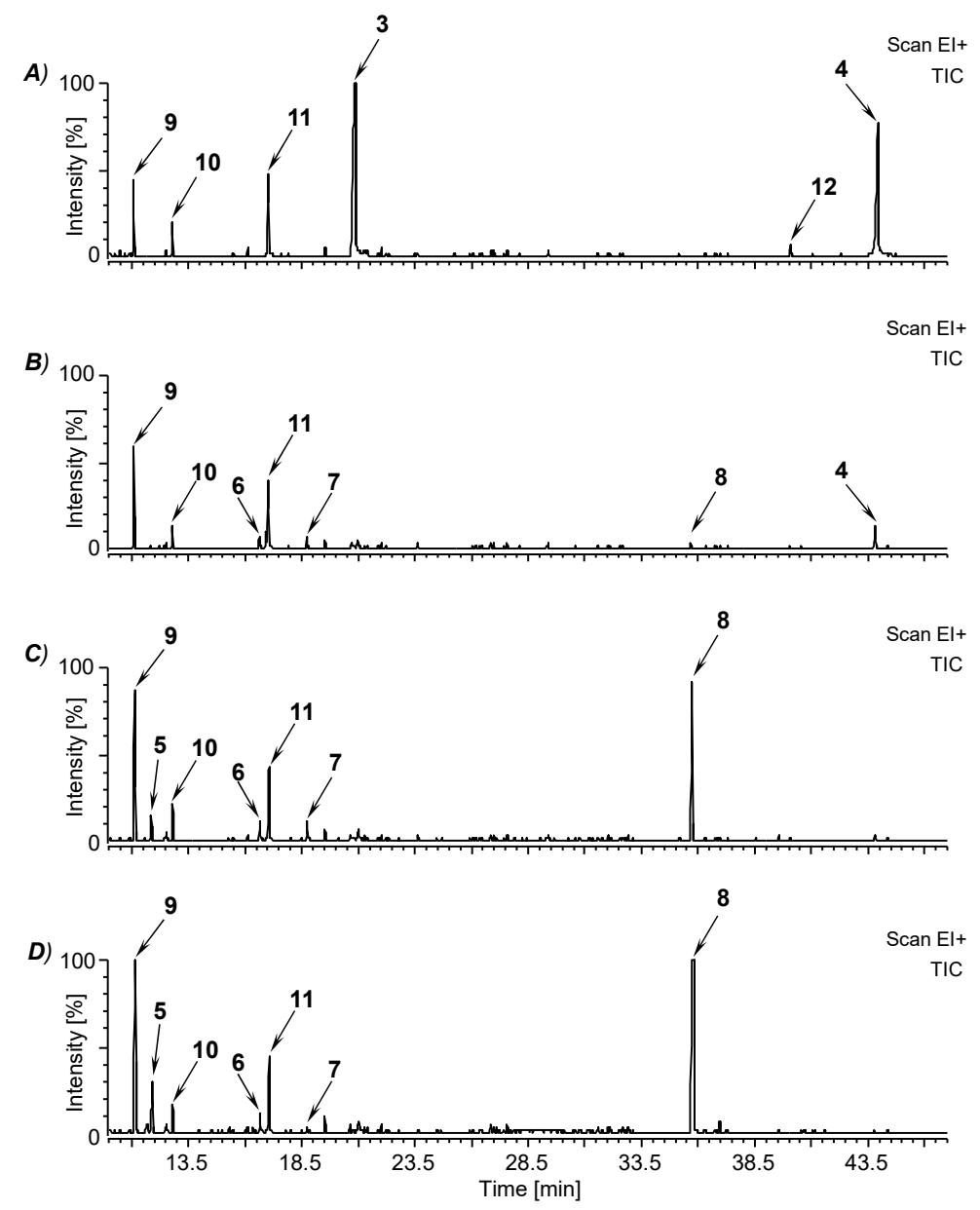

Figure 2. Sections of GC-MS profiles (EI) showing metabolites of M. perennis root extracts. (A) Before $(t=0$ days); (B) after 1 day (C); after 6 days and (D) after 14 days of fermentation with Pediococcus sp. (PP1). For compound assignment, see Table 2.

In the course of fermentation, after 6 days, a prominent peak at retention time $35.8 \mathrm{~min}$ appeared (Figure 2C). This compound exhibited a molecular ion $[\mathrm{M}]^{+}$at $\mathrm{m} / \mathrm{z} 280$ (Table 2) in the EI mass spectrum but could not be readily assigned.

The fragmentation pattern of this molecule was similar to that of chrysohermidin 4 (Table 2), and the even numbered $[\mathrm{M}]^{+}$also points to a dimeric compound, containing two nitrogen atoms. From a strong yellow-green fluorescent spot, which was observed in the TLC of the AcOEt extract (excitation wavelength: $366 \mathrm{~nm}$, see Supplementary Materials, Figures S1 and S2) and which correlated with the compound, this constituent is concluded to carry a UV fluorescent chromophore, probably a maleimide [45]. For unequivocal structure assignment, an attempt was made to isolate this particular compound. By EtOAc extraction of a fermentation broth, obtained by fermentation of herbal parts from M. perennis in accordance with a GHP (German Homoeopathic Pharmacopoeia) literature procedure [32], a fraction was yielded containing the target analyte. The pure compound was recovered 
(yield: $5.4 \mathrm{mg} / \mathrm{L}$ fermentation broth) by subsequent purification via vacuum liquid chromatography (VLC) and centrifugally accelerated thin layer chromatography (CTLC) [35] on silica. The ${ }^{1} \mathrm{H}-\mathrm{NMR}$ spectrum of the pure isolated compound revealed only two different spin systems: a MeN group $(\delta(\mathrm{H}) 4.14(s))$ and a MeO group $(\delta(\mathrm{H}) 3.05(s))$. Based on mass spectral, ${ }^{1} \mathrm{H}$ and ${ }^{13} \mathrm{C}$ NMR data (see Supplementary Materials, Figures S5 and S6) and comparison with the literature, the compound was identified as plicatanin B (bis-(3-methoxy-1N-methylmaleimide); 8), which had previously been isolated from Chrozophora plicata (Euphorbiaceae family) [36]. An $\alpha$-glucosidase inhibitory activity was detected in vitro for compound 8 by the same authors [36].

It is particularly noteworthy that in the course of our investigation also the monomer 5 (3-methoxy$1 \mathrm{~N}$-maleimide, Mw $141 \mathrm{Da}$ ) was obtained from the same fermentation broth. It was detected after TLC separation as a light-blue fluorescent spot (Supplementary Materials, Figures S1 and S2) and in GC-MS analyses as a peak at retention time 11.9 min. Further, $\mathbf{5}$ was identified by comparing mass spectral data with those of a synthesized reference compound. However, it was found in lower amounts in M. perennis root extracts (Figure 2C,D), fermented with pure cultures of PP1 or LP1, as compared to the dimer plicatanin B (8). When comparing GC-MS chromatograms of root extracts fermented either with PP1 or LP1, both were not significantly different regarding the compound pattern (Supplementary Materials, Figure S9), thus revealing similar enzymatic activities of both LABs. However, differences were observed in fermented aqueous extracts obtained from root or herbal parts. The latter tended to show higher concentrations of $\mathbf{8}$ as deduced from GC-MS analyses (Supplementary Materials, Figure S9).

Moreover, for corroborating structure assignment and to gain further spectroscopic information 8 was synthesized starting from isochrysohermidin (13, Figure 3). For this purpose, 13 [31] was treated in a THF/MeOH solution with $0.25 \mathrm{~N} \mathrm{NaOH}$. After $\mathrm{pH}$ adjustment to 7.0 with $\mathrm{AcOH}$, the intermediate isochrysohermidinic acid (14) thus formed, was decarboxylated upon addition of aqueous bromine $\left(\mathrm{Br}_{2}\right)$ solution according to a method of Pink and Stewart [46].
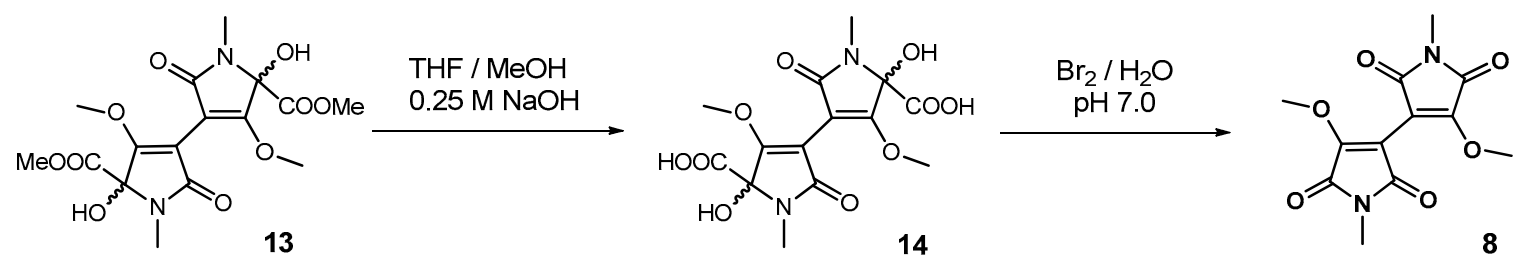

Figure 3. Synthesis of plicatanin B (8) by conversion of isochrysohermidin (13).

After AcOEt extraction and chromatographic purification, plicatanin B (8) was obtained as a pure compound with a $40.8 \%$ yield. The chromatographic and spectroscopic features (GC-MS, LC-MS ${ }^{n}$, NMR) of synthesized 8 were identical to those of the natural constituent obtained upon fermentation. To the best of our knowledge, a total synthesis of $\mathbf{8}$ was hereby accomplished for the first time. In addition to compound 8, GC-MS chromatograms (Figure 2A-D) revealed the formation of mequinol (4-methoxyphenol; 9, retention time $11.1 \mathrm{~min}$ ) upon fermentation. The increase of both compounds was semi-quantitated by evaluation of peak areas of the two analytes 8 and 9 at $t=0,1,3,6$ days (Figure 4). Even though a comparatively short time period of 6 days was monitored, it was found that the formation of $\mathbf{9}$ was slightly delayed compared to that of $\mathbf{8}$ (Figure 4). Comparable findings were also deduced from TLC experiments performed upon fermentation (Supplementary Materials, Figure S2).

Since a precursor molecule of 9 could not be captured by GC-MS, its formation by hydrolytic cleavage of a glycosidic derivative was assumed. To prove this assumption, an AcOEt extract of an unfermented aqueous root extract was silylated together with a methylarbutin (4-methoxyphenol$\beta$-D-glucoside; 15) reference compound. The latter was synthesized from arbutin (4-hydroxyphenol$\beta$-D-glucoside) by methylation with dimethylsulfate and investigated via GC-MS (Figure 5). The retention time and EI mass spectrum of the silylated reference compound (methylarbutin-TMS; 15-TMS) could be aligned with the natural constituent (Figure 5). Even though methylarbutin (15) 
was known before as a plant constituent [47-49], its occurrence in the roots of $M$. perennis has been proven here for the first time. Thus, the cleavage of $\mathbf{1 5}$ by LAB $\beta$-glucosidases (Figure 6) is a conclusive explanation for the increase in the concentration of mequinol (9) upon fermentation. Similar de-glycosylation reactions of plant constituents through the action of microbial enzymes are known from numerous investigations reported in the literature [11,12,50].

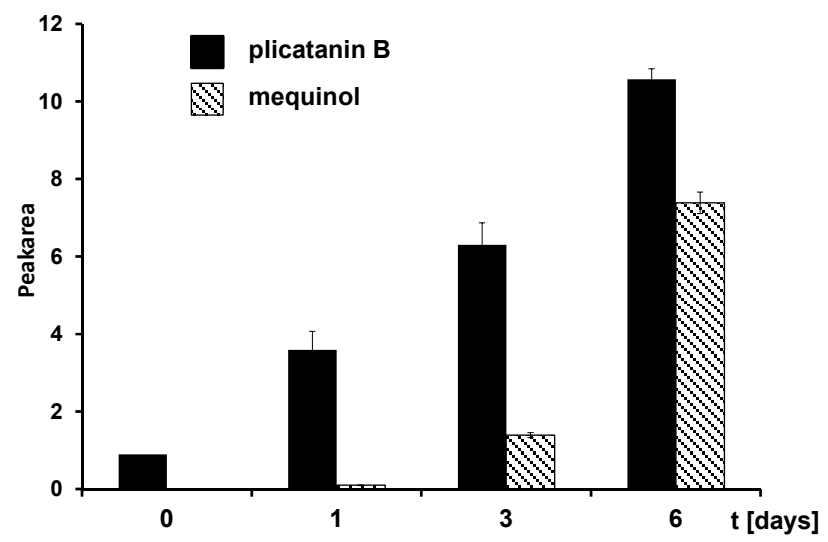

Figure 4. Increase of the peak areas of plicatanin B (8) and mequinol (9) upon fermentation of $M$. perennis aqueous root extracts with Pediococcus sp. (PP1). Peak areas were measured by GC-MS analysis of AcOEt extracts and calculated based on the internal standard eicosane $\left(n-C_{20}\right)$; STD $(n=3)$.
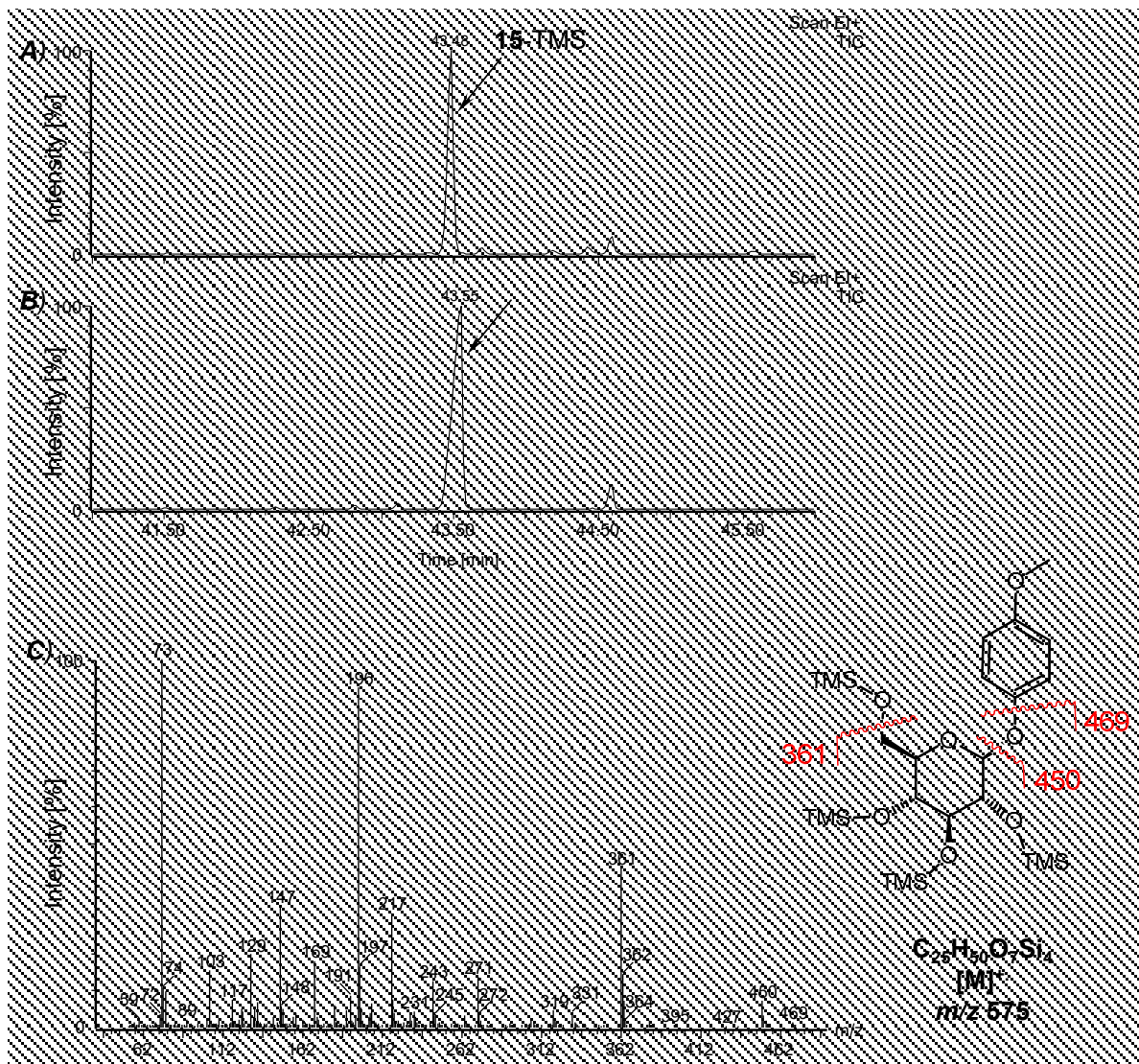

Figure 5. Detection of methylarbutin (15) in an unfermented aqueous extract of M. perennis roots. (A) Section of a GC-MS profile (EI) of an AcOEt extract after silylation. (B) GC-MS of a silylated reference standard. (C) EI mass spectrum of 15-TMS. The red wavy lines illustrate MS fragmentation positions. 


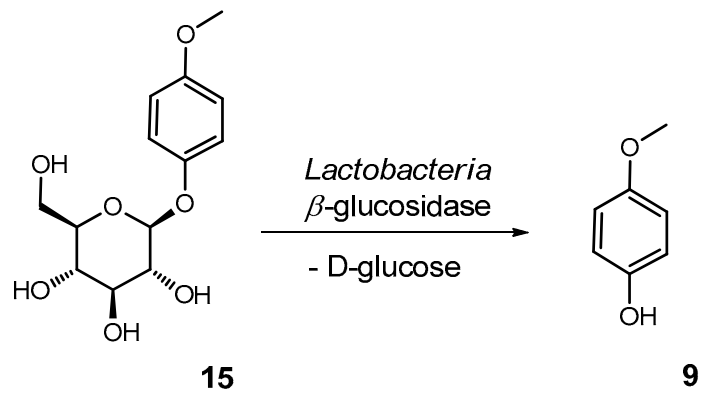

Figure 6. Enzymatic release of mequinol (9) from methylarbutin (15) by Lactobacteria.

\subsection{Approach to the Reaction Mechanism Converting Chrysohermidin (4) into Plicatanin B (8)}

The bioformation of plicatanin B (8) upon LAB fermentation is still not understood from a mechanistic point of view. We could recently demonstrate that chrysohermidin (4), as a dimeric piperidine-2,6-dione, spontaneously reacts in the presence of nucleophiles like methanol via benzilic acid rearrangement, under contraction of both six-membered rings into five-membered rings and esterification to yield isochrysohermidin (13, for structure, see Figure 3) [31]. Hence, a similar reaction of 4 in the presence of water was supposed, which should lead to isochrysohermidinic acid (14) as a further intermediate (Figure 7). The acid $\mathbf{1 4}$ might henceforth react to 8 by step-wise decarboxylation under the influence of microbial enzymes (Figure 7).

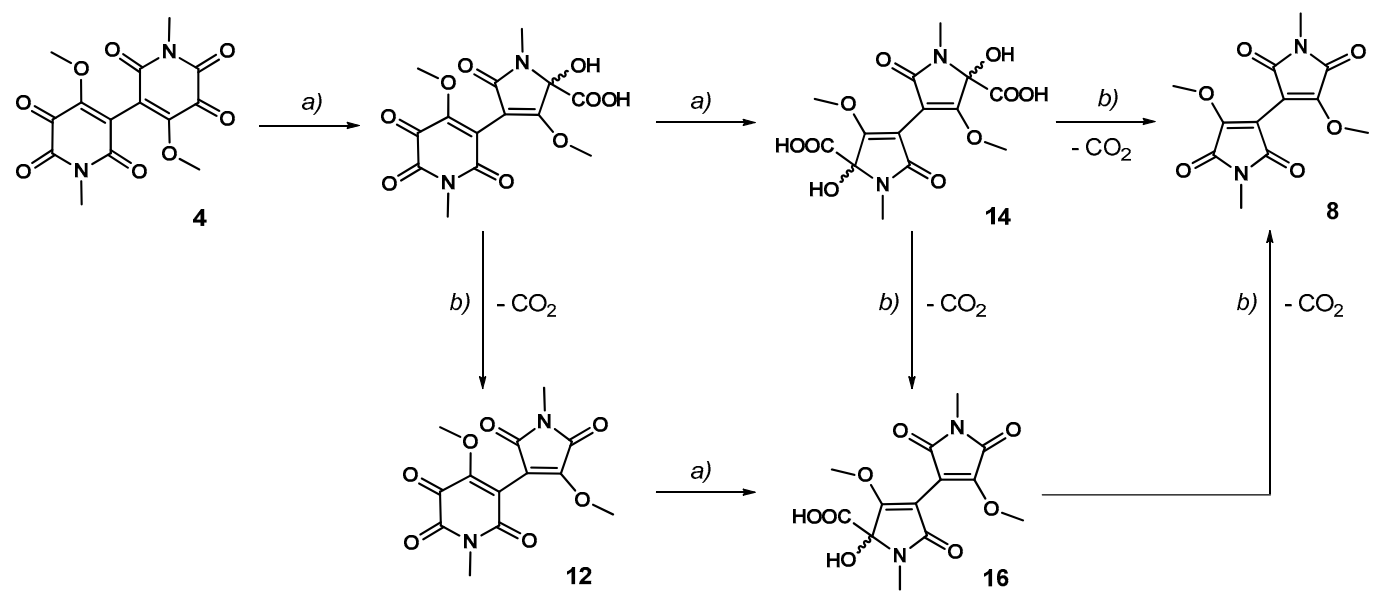

Figure 7. Proposed metabolic pathway of a step-wise conversion of chrysohermidin (4) into plicatanin B (8). (a) Benzilic acid type rearrangement and (b) decarboxylation. The intermediates $\mathbf{1 4}$ and $\mathbf{1 6}$ were detected by LC-MS, while $\mathbf{1 2}$ was analyzed by GC-MS (see Figure 2A).

Since $\mathbf{1 4}$ has not been described in the literature so far, its enrichment from an aqueous extract of $M$. perennis roots by binding onto an anion exchanger $\left(\mathrm{Cl}^{-}\right.$form $)$was performed as a first step. Subsequently, sugars and salts were removed by rinsing the exchanger resin with water. Compound elution and enrichment were achieved with $0.1 \mathrm{~N} \mathrm{HCl}$ and subsequent removal of the aqueous $\mathrm{HCl}$ in vacuo. The obtained fraction was analyzed by $\mathrm{C}_{18}$-RP-HPLC-MS ${ }^{n}$ (Figure 8 ), which shows that the target molecule 14 was enriched by applying the aforementioned steps. The base peak chromatogram revealed a broad peak at low retention time $(2.5-2.8 \mathrm{~min})$ with a supposed molecular ion $[\mathrm{M}+\mathrm{H}]^{+}$at $\mathrm{m} / \mathrm{z}$ 373 (compound 14, Figure 8A,B). This compound did not exhibit a characteristic UV adsorption (data not shown). Thus, structure assignment was based on its mass spectral behavior. Collision-induced dissociation (CID) showed the twofold neutral loss of $\mathrm{CO}_{2}$ and $\mathrm{CH}_{3} \mathrm{OH}$ units from the molecular ion $[\mathrm{M}+\mathrm{H}]^{+}$, yielding fragments at $\mathrm{m} / z 297$ and 221 (Figures $8 \mathrm{C}$ and 9). Subsequent fragmentation revealed the loss of a water molecule from the daughter ion at $m / z 297$ yielding a fragment at $m / z 279$, followed 
by a twofold release of methylisocyanate [Me-N=C=O] from the fragment at $m / z 221$, forming ions at $m / z 164$ and 79, respectively (Figure 9).
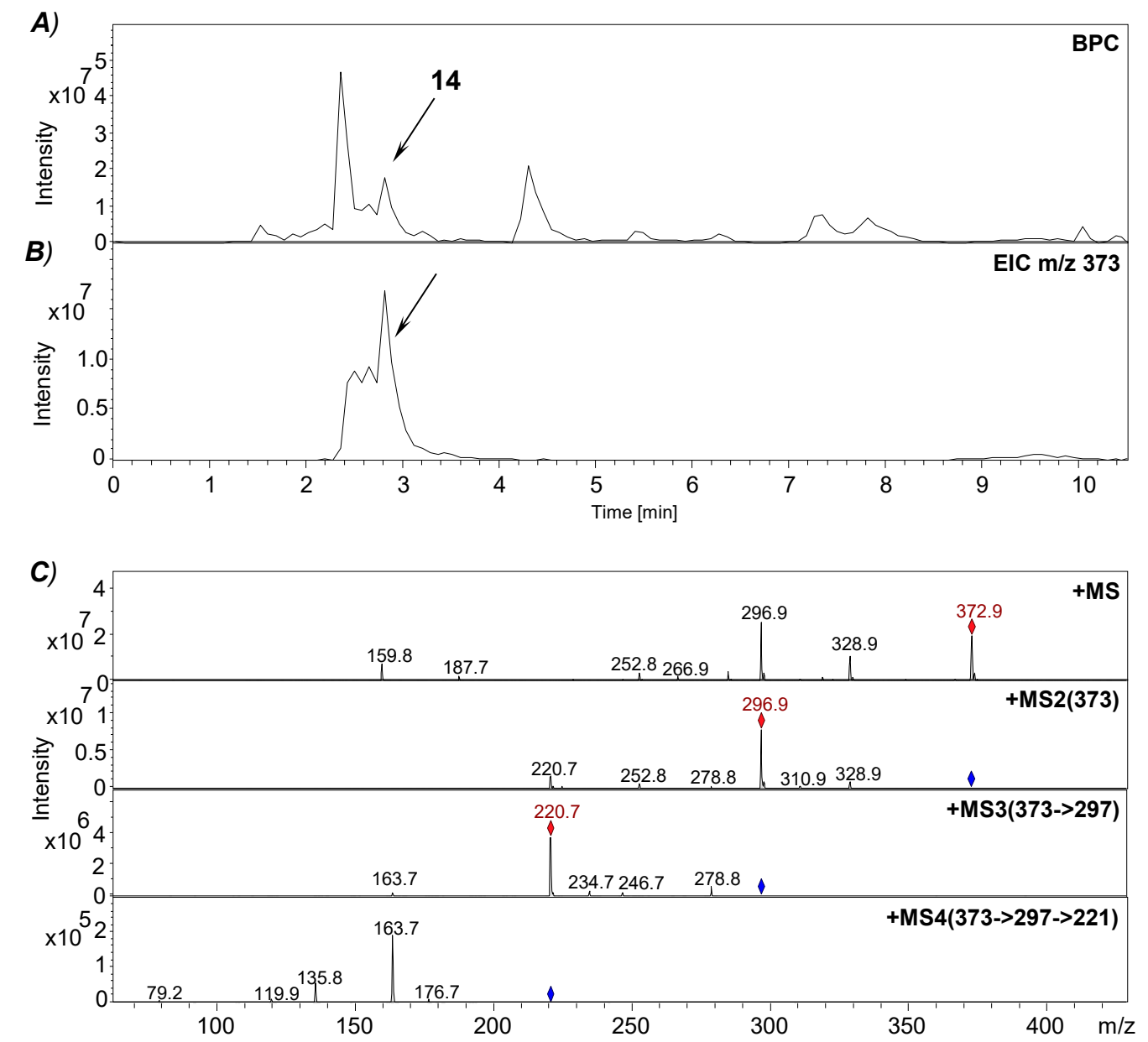

Figure 8. Detection of isochrysohermidinic acid (14) after enrichment from an unfermented aqueous M. perennis root extract by anion exchange chromatography. (A) Section of an LC-MS profile (BPC, positive ionization mode). (B) Extracted ion chromatogram (EIC) for $[\mathrm{M}+\mathrm{H}]^{+}$at $m / z$ 373. (C) Fragmentation of $14\left(\mathrm{C}_{14} \mathrm{H}_{16} \mathrm{~N}_{2} \mathrm{O}_{10} ; \mathrm{Mw} 372.28 \mathrm{Da}\right)$.

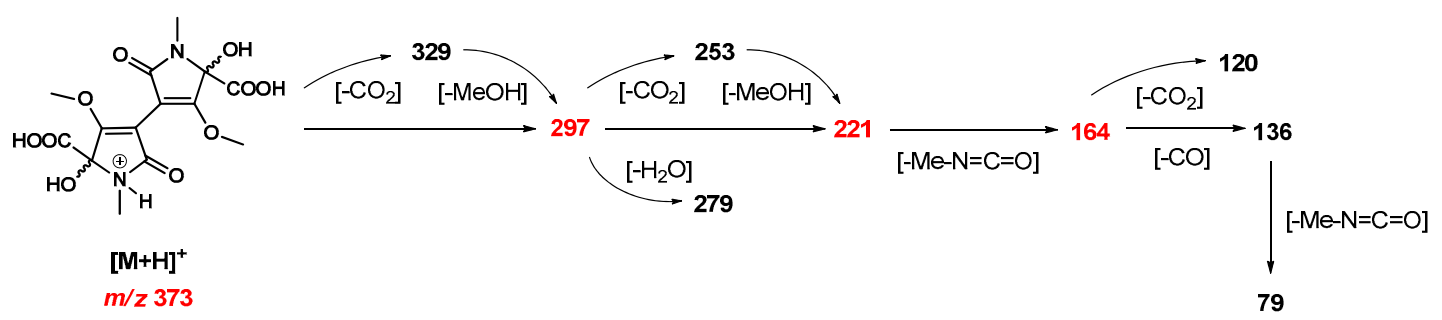

Figure 9. Proposed fragmentation of $\mathbf{1 4}$ upon CID (according to Figure 8C). Red numbers indicate the most intense fragments.

Even though attempts to isolate $\mathbf{1 4}$ from an aqueous extract of M. perennis failed and its total synthesis was not successful, the LC-MS data strongly support the aforementioned structure assignment.

Furthermore, plicatanin B (8) and the proposed intermediates 14 and 16 (Figure 7) were analyzed in the unfermented and fermented aqueous root extract of $M$. perennis by LC-MS, applying single ion extraction of the respective molecular ions $[\mathrm{M}+\mathrm{H}]^{+}$(Figure $10 \mathrm{~A}, \mathrm{~B}$, retention time 2.3 and $13.5 \mathrm{~min}$ ). In addition, 8 (retention time $40.6 \mathrm{~min}$ ) was assigned by a reference standard (data not shown). Moreover, the proposed intermediate 12 (Figure 7) could be detected as a small peak at retention time 
$40.0 \mathrm{~min}$ in the GC-MS chromatogram of an AcOEt extract obtained from the unfermented aqueous root extract (Figure 2A, Table 2).
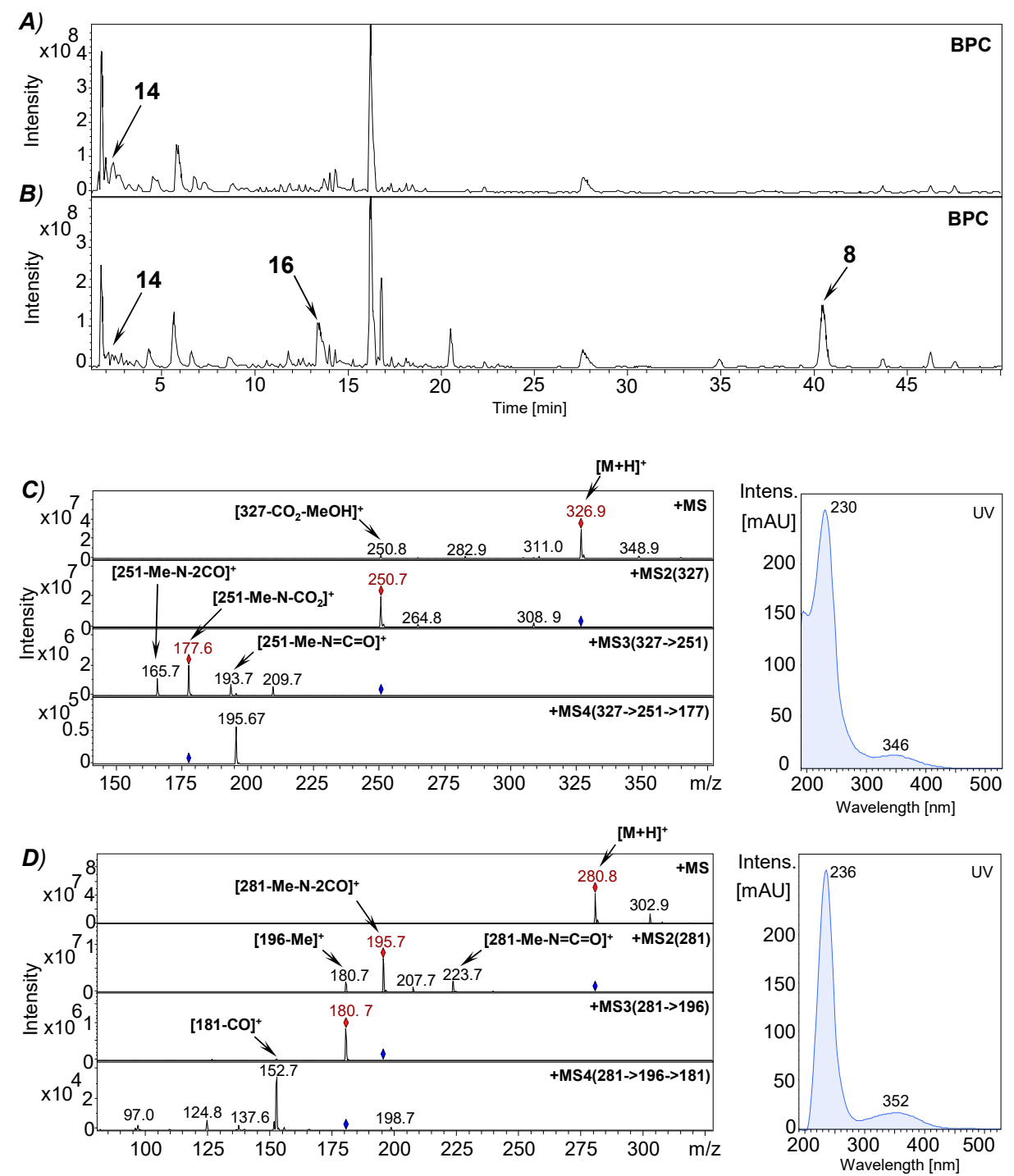

Figure 10. Detection of isochrysohermidinic acid (14), intermediate $\mathbf{1 6}$ and plicatanin B (8) in an unfermented and Pediococcus sp. (PP1) fermented aqueous extract from M. perennis roots. (A) Section of an LC-MS profile (BPC, positive ionization mode) of the unfermented extract. (B) LC-MS profile of the fermented extract (14 d). (C) MS ${ }^{n}$ data of $\mathbf{1 6}\left(\mathrm{C}_{13} \mathrm{H}_{14} \mathrm{~N}_{2} \mathrm{O}_{8} ; \mathrm{Mw} 326.26 \mathrm{Da}\right)$. (D) MS data of 8 $\left(\mathrm{C}_{12} \mathrm{H}_{12} \mathrm{~N}_{2} \mathrm{O}_{6} ; \mathrm{Mw} 280.23 \mathrm{Da}\right)$. UV spectra of the respective compounds are illustrated on the right.

The mass spectrometric behavior of the proposed intermediate 16 (Figure 10C) was similar to that of 14, i.e., it showed the release of a $\left[\mathrm{CO}_{2}-\mathrm{MeOH}\right]$ unit from the molecular ion $[\mathrm{M}+\mathrm{H}]^{+}$at $m / z$ 327, yielding a fragment at $m / z 251$, being characteristic of a pyrrolidone-1-hydroxycarboxylic acid unit (Figure 10C). The latter showed the subsequent release of $[\mathrm{Me}-\mathrm{N}=\mathrm{C}=\mathrm{O}],\left[\mathrm{Me}-\mathrm{N}-\mathrm{CO}_{2}\right]$ and [Me-N-2CO] units from the $\mathrm{N}$-methyl-maleimide core structure yielding fragments at $\mathrm{m} / \mathrm{z} 194,178$ and 166, respectively. The latter fragmentation was also observed for 8 (Figure 10D). Further, the UV spectra of 8 and $\mathbf{1 6}$ (Figure 10) are characteristic of maleimides [45], thus corroborating structure assignment. The detected intermediates 12, 14 and 16 support the proposed reaction mechanism (Figure 7). Starting from chrysohermidin (4), a concerted reaction path consisting of benzilic acid rearrangements, which may spontaneously proceed in the presence of water [31], and subsequent conversion of the pyrrolidone-1-hydroxycarboxylic acid units in the presence of LAB decarboxylases, 
finally yields plicatanin B (8). The high decarboxylase activity of LAB cultures is known from the literature [51,52]. As a result, further plant constituents such as coumaric or caffeic acid derivatives are converted by LAB phenolic acid decarboxylases to form vinylphenols or ethylphenols [53-55].

\section{Conclusions}

Fermentation of medicinal plant constituents is still poorly described in the literature. The fermentation model used in the present study allows detailed investigations of the conversion of individual plant metabolites due to the activity of isolated microorganisms. We could demonstrate that the incubation of aqueous extracts with homo-fermentative Lactobacillus sp. (LP1) and Pediococcus sp. (PP1) follows a complex conversion route of the genuine plant constituents, which is due to the versatile set of LAB enzymes. In comparison, spontaneous fermentation with a wild bacterial flora expectedly yields preparations with higher variance in their chemical profiles. Results from such a fermentation model lay a general basis for the production of tailored fermented extracts from M. perennis but also from other medicinal plants with isolated Lactobacteria strains. Therefore, the application of starter cultures in medicinal plant fermentation practice may help to speed up or improve the control of fermentation processes, aiming at the standardization of extracts containing pharmaceutically active components. Moreover, the use of Lactobacteria opens up the possibility of a "green chemistry" process leading to isolated active ingredients like plicatanin B (8), which are otherwise costly to obtain by chemical total synthesis. Future studies may show a correlation between the bioactivity of such fermented extracts and the applied fermentation process.

Supplementary Materials: The supplementary materials are available online at http://www.mdpi.com/2311-5637/ 5/2/42/s1.

Author Contributions: Design of the study: P.L., D.R.K., F.C.S.; preparation of extracts, fermentation experiments, synthesis of reference compounds: P.L., M.B.; data acquisition: P.L., M.B.; NMR data interpretation: P.L., J.C.; DNA genotypization: S.S.; evaluation of the data and preparation of the manuscript: P.L., M.B., S.S., D.R.K., and F.C.S.

Acknowledgments: The authors want to thank Dorothee Hagemann (WALA Heilmittel GmbH) for preparing fermented aqueous extracts according to GHP protocols. We are also grateful to Regina Herrmann, Monika Pickl and Cornelia Rechert (WALA Heilmittel $\mathrm{GmbH}$ ) for assistance in the cultivation of the microorganisms. Rhinaixa Duque-Thüs (Institute of Botany, Hohenheim University) is acknowledged for the identification of the plant specimens. We thank Mario Wolf (Institute of Chemistry, Hohenheim University) for assistance in NMR measurements, and Jennifer Baer-Engel (WALA Heilmittel GmbH) is gratefully acknowledged for proofreading of the manuscript.

Conflicts of Interest: The authors declare no conflict of interest.

\section{References}

1. Daeschel, M.A.; Andersson, R.E.; Fleming, H.P. Microbial ecology of fermenting plant materials. FEMS Microbiol. Rev. 1987, 46, 357-367. [CrossRef]

2. Kok, C.R.; Hutkins, R. Yogurt and other fermented foods as sources of health-promoting bacteria. Nutr. Rev. 2018, 76 (Suppl. 1), 4-15. [CrossRef]

3. Muck, R.E.; Nadeau, E.M.G.; McAllister, T.A.; Contreras-Govea, F.E.; Santos, M.C.; Kung, L., Jr. Silage review: Recent advances and future uses of silage additives. J. Dairy Sci. 2018, 101, 3980-4000. [CrossRef]

4. Feng, Y.; Zhang, M.; Mujumdar, A.S.; Gao, Z. Recent research process of fermented plant extract: A review. Trends Food Sci. Technol. 2017, 65, 40-48. [CrossRef]

5. Touret, T.; Oliveira, M.; Semedo-Lemsaddek, T. Putative probiotic lactic acid bacteria isolated from sauerkraut fermentations. PLoS ONE 2018, 13, e0203501. [CrossRef]

6. Hussain, A.; Bose, S.; Wang, J.-H.; Yadav, M.K.; Mahajan, G.B.; Kim, H. Fermentation, a feasible strategy for enhancing bioactivity of herbal medicine. Food Res. Int. 2016, 81, 1-16. [CrossRef]

7. Lorenz, P.; Stintzing, F.C. Die Fermentation als innovatives Verfahren zur Gewinnung von Arzneipflanzenauszügen. In Anthroposophische Pharmazie, 1st ed.; Meyer, U., Pedersen, P.A., Eds.; Salumed Verlag: Berlin, Germany, 2016; pp. 663-681. 
8. Van Duynhoven, J.; Vaughan, E.E.; van Dorsten, F.; Gomez-Roldan, V.; de Vos, R.; Vervoort, J.; van der Hooft, J.J.; Roger, L.; Draijer, R.; Jacobs, D.M. Interactions of black tea polyphenols with human gut microbiota: Implications for gut and cardiovascular health. Am. J. Clin. Nutr. 2013, 98, 1631S-1641S. [CrossRef]

9. Luca, S.V.; Macovei, I.; Bujor, A.; Miron, A.; Skalicka-Woźniak, K.; Aprotosoaie, A.C.; Trifan, A. Bioactivity of dietary polyphenols: The role of metabolites. Crit. Rev. Food Sci. Nutr. 2019, 7, 1-34. [CrossRef]

10. Rizzello, C.G.; Coda, R.; Macías, D.S.; Pinto, D.; Marzani, B.; Filannino, P.; Giuliani, G.; Paradiso, V.M.; Di Cagno, R.; Gobbetti, M. Lactic acid fermentation as a tool to enhance the functional features of Echinacea spp. Microb. Cell. Fact. 2013, 12, 40. [CrossRef]

11. Lei, V.; Amoa-Awua, W.K.A.; Brimer, L. Degradation of cyanogenic glycosides by Lactobacillus plantarum strains from spontaneous cassava fermentation and other microorganisms. Int. J. Food Microbiol. 1999, 53, 169-184. [CrossRef]

12. Lee, N.-K.; Paik, H.-D. Bioconversion using lactic acid bacteria: Ginsenosides, GABA, and phenolic compounds. J. Microbiol. Biotechnol. 2017, 27, 869-877. [CrossRef]

13. Lee, S.O.; Kim, S.J.; Kim, J.S.; Ji, H.; Lee, E.O.; Lee, H.J. Comparison of the main components and bioactivity of Rhus verniciflua Stokes extracts by different detoxification processing methods. BMC Complement. Altern. Med. 2018, 18, 242. [CrossRef]

14. Millet, A.; Stintzing, F.; Merfort, I. Validation of a GC-FID method for rapid quantification of nicotine in fermented extracts prepared from Nicotiana tabaccum fresh leaves and studies of nicotine mebabolites. J. Pharm. Biomed. Anal. 2009, 49, 1166-1171. [CrossRef] [PubMed]

15. Millet, A.; Stintzing, F.; Merfort, I. Flavonol quantification and stability of phenolics in fermented extracts from fresh Betula pendula leaves. J. Pharm. Biomed. Anal. 2010, 53, 137-144. [CrossRef] [PubMed]

16. Schwarzenberger, M.; Stintzing, F.; Meyer, U.; Lindequist, U. Biochemical, microbiological and phytochemical studies on aqueous-fermented extracts from Atropa belladonna L. Part 1 - biochemistry and microbiology; Part 2 - Phytochemistry. Pharmazie 2012, 67, 331-344.

17. Duckstein, S.M.; Stintzing, F.C. LC-MS(n) characterization of steroidal saponins in Helleborus niger L. roots and their conversion products during fermentation. Steroids 2015, 93, 47-59. [CrossRef] [PubMed]

18. Knittel, D.N.; Stintzing, F.C.; Kammerer, D.R. Metabolic fate of cardiac glycosides and flavonoids upon fermentation of aqueous sea squill (Drima maritima L.) extracts. J. Pharm. Biomed. Anal. 2015, 110, 100-109. [CrossRef]

19. Lorenz, P.; Beckmann, C.; Felenda, J.; Meyer, U.; Stintzing, F.C. Das Waldbingelkraut (Mercurialis perennis L.) Pharmakognosie einer alten Arzneipflanze. Z. Phytother. 2013, 34, 40-46. [CrossRef]

20. Rugman, F.; Meecham, J.; Edmondson, J. Mercurialis perennis (dog's mercury) poisoning: A case of mistaken identity. Br. Med. J. (Clin. Res. Ed.) 1983, 287, 1924. [CrossRef]

21. Watson, P.J. Suspected dog's mercury (Mercurialis perennis) poisoning in cattle. Vet. Rec. 1998, 142, $116-117$. [CrossRef]

22. Welchman, D.B.; Gibbens, J.C.; Giles, N.; Piercy, D.W.; Skinner, P.H. Suspected annual mercury (Mercurialis annua) poisoning of lambs grazing fallow arable land. Vet. Rec. 1995, 137, 592-593. [PubMed]

23. Lorenz, P.; Duckstein, S.; Conrad, J.; Knödler, M.; Meyer, U.; Stintzing, F.C. An approach to the chemotaxonomic differentiation of two European dog's mercury species: Mercurialis annua L. and M. perennis L. Chem. Biodivers. 2012, 9, 282-294. [CrossRef] [PubMed]

24. Swan, G.A. Hermidin, a chromogen from Mercurialis perennis L. Experientia 1984, 40, 687-688. [CrossRef]

25. Swan, G.A. Isolation, structure and synthesis of hermidin, a chromogen from Mercurialis perennis L. J. Chem. Soc. Perkin Trans. I 1985, 1757-1766. [CrossRef]

26. Lorenz, P.; Hradecky, M.; Berger, M.; Bertrams, J.; Meyer, U.; Stintzing, F.C. Lipophilic constituents from aerial and root parts of Mercurialis perennis L. Phytochem. Anal. 2010, 21, 234-245. [CrossRef] [PubMed]

27. Lorenz, P.; Conrad, J.; Bertrams, J.; Berger, M.; Duckstein, S.; Meyer, U.; Stintzing, F.C. Investigations into the phenolic constituents of dog's mercury (Mercurialis perennis L.) by LC-MS/MS and GC/MS analyses. Phytochem. Anal. 2012, 23, 60-71. [CrossRef]

28. Lorenz, P.; Knödler, M.; Bertrams, J.; Berger, M.; Meyer, U.; Stintzing, F.C. n-Alkylresorcinol occurrence in Mercurialis perennis L. (Euphorbiaceae). Z. Naturforsch. 2010, 65c, 174-179. [CrossRef]

29. Lorenz, P.; Heinrich, M.; Conrad, J.; Heller, A.; Stintzing, F.C.; Kammerer, D.R. Comprehensive characterization of $n$-alkylresorcinols and other lipid constituents of Mercurialis tomentosa L. from Alicante, Spain. Chem. Biodiv. 2017, 14. [CrossRef] 
30. Lorenz, P.; Conrad, J.; Stintzing, F.C. Metabolic fate of depsides and alkaloid constituents in aqueous extracts from Mercurialis perennis L. during fermentation. Chem. Biodivers. 2013, 10, 1706-1723. [CrossRef]

31. Lorenz, P.; Conrad, J.; Duckstein, S.; Kammerer, D.R.; Stintzing, F.C. Chemistry of hermidin: Insights from extraction experiments with the main alkaloid of Mercurialis perennis L. tracked by GC/MS and LC/MS ${ }^{\mathrm{n}}$. Helv. Chim. Acta 2014, 97, 1606-1623. [CrossRef]

32. GHP, German Homoeopathic Pharmacopoeia, Homöopathisches Arzneibuch, Spezielle Herstellungsvorschriften, Vorschrift 34 c; Deutscher Apotheker-Verlag: Stuttgart, Germany; Govi Pharmazeutischer Verlag: Eschborn, Germany, 2018.

33. Stevens, H.; Brinkhoff, T.; Simon, M. Composition of free-living, aggregate-associated and sediment surface-associated bacterial communities in the German Wadden Sea. Aquat. Microb. Ecol. 2005, 38, 15-30. [CrossRef]

34. National Center for Biotechnology Information (NCBI). Available online: http://www.ncbi.nlm.nih.gov/blast/ (accessed on 13 April 2019).

35. Agrawal, V.; Desai, S. Centrifugally accelerated thin layer chromatography for isolation of marker compounds and bioactives. J. Pharmacogn. Phytochem. 2015, 3, 145-149.

36. Tabussum, A.; Riaz, N.; Saleem, M.; Ashraf, M.; Ahmad, M.; Alam, U.; Jabeen, B.; Malik, A.; Jabbar, A. $\alpha$-Glucosidase inhibitory constituents from Chrozophora plicata. Phytochem. Lett. 2013, 6, 614-619. [CrossRef]

37. Tedaldi, L.M.; Smith, M.B.; Nathani, R.I.; Baker, J.R. Bromomaleimides; new reagents for selective and reversible modification of cysteine. Chem. Commun. 2009, 43, 6583-6585. [CrossRef]

38. Gill, G.B.; James, G.D.; Oates, K.V.; Pattenden, G. The synthesis of 5-ylidenepyrrol-2(5H)-ones from maleimides and from pyrrol-2-(5H)-ones. J. Chem. Soc. Perkin Trans. I 1993, 2567-2579. [CrossRef]

39. Gabrielle, S.-P.; Dafik, L.; Klegraf, E.; Hanessian, S. Stereocontrolled synthesis of phenolic $\alpha$-D-glucopyranosides. Synthesis 2016, 48, 3575-3588, Suppl. Materials S6.

40. Lutterbach, R.; Stöckigt, J. Dynamics of the biosynthesis of methylursubin in plant cells employing in vivo ${ }^{13}$ C NMR without labeling. Phytochemistry 1995, 40, 801-806. [CrossRef]

41. Simpson, W.J.; Taguchi, H. The genus Pediococcus, with notes on the genera Tetratogenococcus and Aerococcus. In The Genera of Lactic Acid Bacteria; Wood, B.J.B., Holzapfel, W.H., Eds.; Chapman \& Hall: London, UK, 1995; pp. 125-172.

42. Salvetti, E.; Torriani, S.; Felis, G.E. The genus Lactobacillus: A taxonomic update. Probiotics Antimicrob. Proteins 2012, 4, 217-226. [CrossRef] [PubMed]

43. Hammes, W.P.; Vogel, R.F. The genus Lactobacillus. In The genera of lactic acid bacteria. The lactic acid bacteria, Vol 2; Wood, B.J.B., Holzapfel, W.H., Eds.; Springer: Boston, MA, USA, 1995; pp. 19-54.

44. Felis, G.E.; Salvetti, E.; Torriani, S. Systematics of Lactic Acid Bacteria: Current Status. In Biotechnology of Lactic Acid Bacteria: Novel Applications; Mozzi, F., Raya, R.R., Vignolo, G.M., Eds.; John Wiley \& Sons, Ltd.: Chichester, West Sussex, UK, 2016; pp. 25-31.

45. Xie, Y.; Husband, J.T.; Torrent-Sucarrat, M.; Yang, H.; Liu, W.; O’Reilly, K.O. Rational design of substituted maleimide dyes with tunable fluorescence and solvafluorochromism. Chem. Commun. 2018, 54, 3339-3342. [CrossRef] [PubMed]

46. Pink, J.M.; Stewart, R. Mechanism of oxidative decarboxylation of $\alpha$-hydroxy acids by bromine water. Part I. Oxidation in neutral and alkaline medium. Can. J. Chem. 1971, 49, 649-653. [CrossRef]

47. Sticher, O.; Soldati, F.; Lehmann, D. High-performance liquid chromatographic separation and quantitative determination of arbutin, methylarbutin, hydroquinone and hydroquinone-monomethylether in Arctostaphylos, Bergenia, Calluna and Vaccinium species. Planta Med. 1979, 35, 253-261. [CrossRef]

48. Dusková, J.; Dusek, J.; Jahodár, L. Bergenia crassifolia (L.) Fritsch in vitro. Ceska Slov. Farm. 2001, 50, 83-85. [PubMed]

49. Flores-Bocanegra, L.; Pérez-Vásquez, A.; Torres-Piedra, M.; Bye, R.; Linares, E.; Mata, R. $\alpha$-Glucosidase inhibitors from Vauquelinia corymbosa. Molecules 2015, 20, 15330-15342. [CrossRef] [PubMed]

50. Lee, Y.; Oh, J.; Jeong, Y.-S. Lactobacillus plantarum-mediated conversion of flavonoid glycosides into flavonols, quercetin, and kaempferol in Cudrania tricuspidata leaves. Food Sci. Biotechnol. 2015, 24, 1817-1821. [CrossRef]

51. Yokoyama, M.T.; Carlson, J.R. Production of skatole and para-cresol by a rumen Lactobacillus sp. Appl. Environ. Microbiol. 1981, 41, 71-76. [PubMed]

52. Barbieri, F.; Montanari, C.; Gardini, F.; Tabanelli, G. Biogenic amine production by lactic acid bacteria: A review. Foods 2019, 8, 17. [CrossRef] 
53. Van Beek, S.; Priest, F.G. Decarboxylation of substituted cinnamic acids by lactic acid bacteria isolated during malt whisky fermentation. Appl. Environ. Microbiol. 2000, 66, 5322-5328. [CrossRef] [PubMed]

54. Rodríguez, H.; Landete, J.M.; Curiel, J.A.; de Las Rivas, B.; Mancheño, J.M.; Muñoz, R. Characterization of the p-coumaric acid decarboxylase from Lactobacillus plantarum CECT 748(T). J. Agric. Food Chem. 2008, 56, 3068-3072. [CrossRef]

55. Rodríguez, H.; Curiel, J.A.; Landete, J.M.; de las Rivas, B.; López de Felipe, F.; Gómez-Cordovés, C.; Mancheño, J.M.; Muñoz, R. Food phenolics and lactic acid bacteria. Int. J. Food Microbiol. 2009, 132, 79-90. [CrossRef]

(C) 2019 by the authors. Licensee MDPI, Basel, Switzerland. This article is an open access article distributed under the terms and conditions of the Creative Commons Attribution (CC BY) license (http://creativecommons.org/licenses/by/4.0/). 